\title{
Spillover Effects of Foreign Direct Investment: How do Region-specific Institutions Matter?
}

\section{Abstract:}

- This study examines the role of region-specific institutions in explaining foreign direct investment (FDI) spillovers.

- The findings reveal that domestic firms in different regions of China do not equally benefit from inward FDI. Firms that operate in regions with higher levels of intellectual property right (IPR) protection, market development and international openness are better able to absorb spillovers and improve their productivity.

- By demonstrating how subnational location-bound institutions influence the spillover effects of FDI, the paper extends prior literature that largely focuses on either firm- and industry-specific determinants or on country-level institutional idiosyncrasies.

Keywords: Foreign direct investment $\cdot$ Spillovers $\cdot$ Productivity $\cdot$ Regions $\cdot$ Chinese firms 


\section{Introduction}

Foreign direct investment (FDI) generates spillovers that often benefit local firms in the host country. As both foreign and local firms have to accommodate institutional conditions that vary not only between countries, but also within the host economy (Wright et al. 2005), institutions shape the choices, behaviour, interaction and performance of firms and, consequently, influence the spillovers that advantage local firms. In this study, we examine how region-specific institutions affect FDI spillovers. Despite the view that FDI generates spillovers that benefit local firms in the host country, research on this topic has yielded a mixed set of results (see Görg and Greenaway 2004), including positive effects (Buckley et al. 2002; Liu et al. 2009; Wang et al. 2012a), negative effects (e.g., Feinberg and Majumdar 2001; Jordaan 2009), marginal effects (e.g., Haskel et al. 2002) and a nonlinear relationship between foreign presence and local firms' performance (Girma 2005; Girma et al. 2007; Buckley et al. 2007a).

As one of the largest FDI destinations, China has attracted considerable scholarly attention. Some studies examine whether the presence of FDI affects the productivity of domestic firms and report positive spillovers (e.g., Buckley et al. 2002, 2007a; Liu et al. 2009; Wei and Liu 2006). Others look into the conditions under which spillovers occur, such as how the diversity of country of origin (Buckley et al. 2007a; Zhang et al. 2010) and process of entry (speed and irregularity) influence FDI spillovers (Wang et al. 2012a), or the types of domestic firms and industries that benefit from spillovers (e.g., Buckley et al. 2007b). These studies typically find that the occurrence and magnitude of FDI spillovers depend upon a number of contingencies, implying that not all firms can benefit from FDI. Nevertheless, despite a large volume of studies, more research on FDI spillovers is required to identify the conditions under which such effects are large, small or non-existent.

Extant research on China and other countries has two important limitations. First, although institutions, defined as the rules of the game (North 1990), shape firm behavior, choices and performance, the link between institutions and FDI spillovers has been overlooked. Second, many studies focus on multiple countries or sectors, but we still know little about whether the observed firm-specific spillover effects of FDI are contingent on, or independent of, the context of subnational regions. The characteristics of a region are critical for understanding FDI spillovers because differences in factor endowments influence not only the levels of inward FDI in a region, but also the potential for spillovers from FDI. To address these gaps, this paper examines how FDI spillovers are affected by region-specific institutions, including intellectual property right (IPR) protection, market development, and international openness, within a given country. These three constructs capture different dimensions of region-specific economic institutions and collectively influence not only the 
transfer and development of technology in foreign firms (and thus the spillover potential) but also the absorptive capacity of domestic firms and therefore the effects of FDI spillovers.

The paper extends the prior literature in three directions. First, the extant international business literature suggests that institutions, such as regulatory and political institutions, may influence how much FDI a country can attract (Meyer and Nguyen 2005; Zhou et al. 2002). However, the question of how geographically localized characteristics influence the extent to which local firms benefit from the presence of technologically advanced MNEs remains under-theorized. This is a surprising lacuna since the institutional idiosyncrasies that attract FDI in a specific region may also influence the effects of such FDI. For instance, firms in regions that possess high quality institutions might also be those best placed to gain from the foreign presence. Accounting for the role of institutions is important when studying FDI spillovers in emerging economies, where institutions are overly complex and rapidly changing. We extend the literature on FDI location choices by examining how region-specific institutions facilitate or constrain the extent to which domestic firms benefit from FDI. Modeling spillovers in this manner enables us to explain how the effects of FDI vary across subnational locations, and establish a conceptual link between two distinct research strands - namely, the antecedents and outcomes of FDI.

Second, regions within a given nation may differ significantly in institutional setups. Prior research (on FDI determinants), however, focuses on country-level institutions, assuming that institutions are homogenous across subnational regions in a country. This neglect of consideration of subnational effects might not be that critical for host countries with relatively homogeneous subnational institutions. However, these effects are likely to be much more important for host countries with heterogeneous institutions across subnational regions, such as China. Yet extant literature offers limited knowledge of how such cross-regional institutional variations influence the effects of FDI on local firms. We argue that variations in region-specific institutions constitute different sets of opportunities and constraints among host country regions, shaping differential regional effects of FDI spillovers. This helps us explain how differences in region-specific institutions can account for a significant portion of the variations in FDI spillovers in different regions, thus adding to the understanding of FDI spillovers in a cross-region context.

Third, a few studies have shown that FDI spillovers have a regional dimension. For example, some studies find that FDI spillovers are confined within regions (Girma et al. 2001; Liu and Wei 2006), while others show that such benefits may spread across other regions (Ke and Lai 2010; Mullen and Williams 2007). Prior research has also examined FDI spillovers at the regional level (Cheung and Lin 2004; Qi et al. 2009; Huang et 
al. 2012). Although these studies help us distinguish between local and inter-regional FDI effects, little is known about how regional institutional characteristics shape the way in which FDI affects local firms within the same region. As such, prior research only provides a partial account of the phenomena of regional FDI spillovers. By examining how region-specific institutions influence the effects of foreign presence on the productivity of local firms, this study shifts the debate from whether spillovers occur along regional lines to the question of under which institutional conditions FDI impacts domestic firms in the same region. Our approach is consistent with a growing stream of research that explicitly recognizes the strategic roles of geographic space (e.g., Girma et al. 2001; Nachum 2000).

China is a particularly suitable context for this study not only because the country has received a large amount of FDI but also because it has undergone major political and economic reforms that haveled to provincial institutions varying greatly (Hong et al. 2014). Our framework - which is tested against a recently constructed large panel dataset comprising 357,958 firms - challenges current thinking about FDI spillovers and demonstrates how the presence of foreign firms interacts with location-bound institutions to jointly shape the spillover effects of FDI.

\section{Institutional Change and FDI in China}

Emerging economies are often characterized by underdeveloped markets, extensive state intervention, inefficient intermediaries and weak contract enforcement (Khanna and Palepu 1997). These in turn increase transaction costs and create uncertainty, influencing firm behavior in a manner that differs from that in developed economies (Khanna and Yafeh 2007; Khanna and Rivkin 2001). Many emerging economies have therefore implemented institutional transitions. The marketization reform in China since 1978 has involved a process of decentralization (Boisot and Meyer 2008). The central government of China delegated responsibility for economic performance and the control of some state-owned enterprises and other organizations to provincial governments (Boisot and Meyer 2008). These reforms devolved regulatory authority from the central to local governments and incentivized provincial governments to promote economic development. Decentralization has created a "Chinese Style Federalism" that is characterized by local protectionism and a greater degree of regional authority over policy-making, legal development and enforcement (Chan et al. 2010).

As a result, unlike Western countries in which institutions are largely homogenous across subnational regions, political and economic reforms in China have created an environment that significantly differs across 
regions. China's transition is characterized by path dependency, political fragmentation and uneven reform of institutions (e.g., Grabher and Stark 1997), leading to a multi-layered institutional system that has evolved in different directions across regions (Peck and Zhang 2013). Although the open-door policy is set by the central government, it is up to the local authorities to decide the specifics of these policies (Chan et al. 2010). For example, while the central government is responsible for regulating the country's FDI-friendly environment (e.g., industries that encourage foreign entry and industries that FDI is denied), local government has the freedom to determine specific FDI policies according to their region's particular set of objectives, priorities and conditions. Hence, the rules and incentives with respect to FDI also significantly differ across regions in China due to the uneven regional development in institutions and markets.

Furthermore, China's development strategy favours certain regions that already enjoyed location advantages. For example, in 1979, the central government allowed Guangdong and Fujian provinces to establish special economic zones that enjoyed institutional and policy benefits in order to attract foreign investment. In 1984, the central government further declared 14 coastal cities as "coastal open cities" which were granted greater authority that paralleled that of the special economic zones. Although coastal regions achieved remarkable growth, the economic prosperity is less in the Central and Western Chinese regions that were left behind. Similarly, although China is one of the world's largest recipients of FDI and many Chinese firms have benefited through learning from foreign firms, by cooperating with original equipment manufacturers (OEM) and by establishing joint ventures (Luo and Tung 2007), FDI is unevenly distributed within China due to the central government's policy orientation and uneven institutional development across regions. In 2007 , more than $80 \%$ of FDI was concentrated in the eastern areas. Out of China's 31 provinces, the two largest recipients, Guangdong and Jiangsu, alone accounted for over $40 \%$ of the country's total FDI (SSB, 2008). By contrast, although government encouraged foreign firms to invest in western provinces, their FDI share remained small.

\section{Theoretical Framework}

FDI and Spillovers

FDI spillovers refer to externalities that occur when the activities of foreign owned firms affect the performance of domestically owned firms. These effects are usually evaluated as the influence of the presence of foreign MNEs on the productivity of local firms (Buckley et al. 2007a). Theory suggests that spillovers can work through a number of channels (Kafouros 2008). The first channel is the "demonstration effect", in which 
a local firm improves its productivity by observing and imitating the technology and management practices of MNE affiliates (Kokko et al. 1996). The second channel is through employee mobility. When employees of foreign affiliates move to domestic firms, the technologies and management practices of MNE subsidiaries diffuse to domestic firms (Kokko, 1996). The third channel functions through competition between firms (Kafouros and Buckley 2008). The entry of foreign firms can force domestic firms to increase their productivity by updating technologies and management practices in order to respond to competitive challenges (Kokko et al. 1996). Unlike the demonstration effect, which is positive, the effects of competition can be negative and reduce the performance of local firms through market stealing, particularly in the markets of final goods and factors (Aitken and Harrison 1999; Buckley et al. 2007a).

Despite the agreement within the international business literature of the existence of spillovers, past empirical results do not always confirm this theory. These inconsistent results might be associated with underlying variability in datasets, empirical specifications and the measurement of productivity (Görg and Strobl 2001). Recognizing that FDI spillovers are not as uniform as many studies assume, more recent work has investigated the conditions under which spillovers might be strong, weak or nonexistent. The findings show that idiosyncrasies such as absorptive capacity, entry modes, industry policy, and the country of origin of foreign investors can explain the disparate results (Buckley et al. 2002; Fortanier 2007). In addition, variations in FDI spillovers between developing, transition and developed economies have been reported (Görg and Greenaway 2004; Meyer and Sinani 2008).

So, despite these apparently disparate findings, prior studies together establish that FDI spillovers are influenced by firm-, industry-, host-, and home-country factors. This implies that location-bound factors, similar to industry-specific characteristics (e.g., Buckley et al. 2007b), should influence the extent to which local firms benefit from the presence of MNEs. Yet, despite the centrality of the concept that geography can explain variations in the effects of FDI, prior research has not investigated how such region-specific institutions affect FDI spillovers. In this study, we argue that cross-regional institutional idiosyncrasies affect the occurrence and magnitude of FDI spillovers both through influencing foreign firms as spillover generators and local firms as spillover receivers.

The Effects of Institutions on FDI Spillovers

Strong institutions reduce transaction costs and uncertainty and provide incentives for certain types of activities (North 1990). Weak institutions, on the other hand, increase monitoring and enforcement costs (Antal-Mokos 
1998), and may hinder organizational performance. As institutions create both opportunities and barriers for FDI, they constitute a critical component of locational advantages - one of the three pillars of the OLI paradigm (Dunning 1993). MNEs choose locations that allow them to arbitrage differences in institutions between the selected location and their home country. Countries and regions with well-developed institutions receive FDI that carries significant technological content (Meon and Sekkat 2008; Ali et al. 2010), because these institutions help foreign firms reduce transaction costs (Meyer et al. 2009), access local networks and complementary resources (Peng 2003; Meyer and Nguyen 2005), and better protect and exploit their technological advantages. All of this increases the potential of technological spillovers to local firms. Institutions also affect entry mode choices by moderating the relative costs of alternative organizational forms (Makino and Beamish 1998; Meyer and Nguyen 2005). A reduction of restrictions on FDI can encourage foreign firms to engage in joint ventures with local firms (Meyer and Nguyen 2005) that may generate more spillovers than wholly owned subsidiaries because of the stronger interaction with local actors. On the other hand, because weak institutional arrangements create information asymmetries and increase the risk of choosing wrong partners (Meyer 2001), firms may prefer to enter such markets using wholly owned subsidiaries, thus reducing the potential for spillovers. Furthermore, government policy influences technology transfer by foreign firms. For example, the Chinese government requires foreign firms to transfer technology to Chinese firms in return for market access (Holmes et al. 2014).

Institutions also influence the absorptive capacity of local firms by shaping the evolution of resources and capabilities (Meyer and Nguyen 2005). Government policies that develop human capital through education and training programmes enhance domestic firms' ability to absorb spillovers from FDI (Lee and Kim 2009), whilst any rigidity of labor market regulations may reduce the absorptive capacity of firms by capping their level of skills (Hale and Long 2011). Equally, stronger IPR protection encourages domestic firms to develop innovative capabilities (Chen and Puttitanun 2005). This in turn enhances the absorptive capacity of domestic firms and facilitates absorption of spillovers. Furthermore, ownership is an important institutional dimension in emerging markets (Cui and Jiang 2012) because it affects how government agencies exercise control through different incentive structures. Ownership type influences strategic firm choices and performance (Boisot and Child, 1996; Wang et al. 2012b), and consequently the absorptive capacity of domestic firms. Prior research indicates that state owned Chinese firms, due to lower absorptive capacity and willingness to learn, are less able to exploit spillovers than non-state Chinese firms (Buckley et al. 2007b). 
Hypotheses

It is often assumed that strong IPR limits the manner in which non-rights holders use proprietary knowledge and may limit opportunities for imitation (Maskus 2000). Because FDI may take the form of superior production technology, MNEs tend to enter regions with strong IPR regulations in order to reduce the probability of imitation and protect their technological advantages (Kafouros et al. 2012). According to this view, the tighter the IPR protection in a subnational region is, the lower the level of knowledge diffusion in the region will be. In contrast, we argue that tighter IPR protection may actually be beneficial for the generation of FDI spillovers. First, stronger IPR protection may encourage foreign firms to transfer technology to the host country. This increases the potential of spillovers to local firms. By contrast, a weak IPR regime will be likely to raise "institutional barriers" that discourage foreign firms from transferring technology, limiting the opportunity of technological learning by local firms.

Second, stronger IPR protection also encourages local firms to innovate. Empirical evidence shows that strong IPR protection and enforcement enhance the innovation of local firms in developing countries (Chen and Puttitanun 2005). As these local firms become more innovative, their absorptive capacity increases, helping the absorption of FDI spillovers. Third, while tighter IPR regulations lower the possibility of imitation and reverse engineering, and reduce the usefulness of labour turnover, since employees that move to local firms cannot pass on the know-how gained from foreign firms, there are other mechanisms through which spillovers may occur. Even if there are no direct technological spillovers, the mere presence of foreign products and technologies provide valuable information about the technological areas which are more promising and what intellectual rights can be claimed in a patent application. This can inspire and stimulate local innovators to develop new products and processes, shorten the trial-and-error process of invention, and enhance productivity.

While firms in developed economies can readily enforce IPR law since strong institutions shield against unlawful imitation (Coriat and Weinstein 2002; Jaffe and Lerner 2004), this is not the case in emerging economies because there is often a weak legal infrastructure and poor enforcement of property rights and contracts (Siebeck et al. 1990). Moreover, in contrast to the typical view that IPR protection within a given nation is similar across its regions, emerging countries exhibit significant cross-regional variations in the extent to which the IPR laws are enforced effectively to protect innovation. Because strong IPR laws encourage R\&D activities and protect proprietary technology, we expect that foreign firms invest more in R\&D or transfer technologies to host regions in which IPR protection and enforcement is strong. By contrast, in regions in 
which IPR enforcement is weak, foreign firms cannot use patents to appropriate returns from innovation. These variations are particularly significant in countries, such as China, that have a short history of using IPR laws to protect innovation and that feature uneven regional development in institutions and markets. Administrative decentralization in China has led regional authorities and provincial governments to have substantial judicial independence and they frequently influence courts' judgments (Peck and Zhang, 2013). Hence, even though the enforcement of IPR often implies a trade-off between the positive incentives to transfer or develop technology and the negative effect arising from an increase in the cost of imitation, we expect a strong IPR regime to enhance the benefits of FDI spillovers for the productivity of domestic firms:

Hypothesis 1: The effects of foreign presence on the productivity of local firms will be higher in regions with stronger IPR protection than in regions with weaker IPR protection.

Regions in large emerging countries also differ in the degree of marketization, defined as the degree to which a region possesses market-oriented institutions (Khanna and Palepu 1997). Although externalities are caused by market failure, the impact of market development on FDI spillovers is under-studied in the literature. We argue that the level of marketization in a region moderates the effects of FDI on domestic firms' productivity. First, foreign firms are more likely to bring with them better technology in regions where markets and technology transfer institutions are well-developed and institutional uncertainty is reduced. This is because intellectual property rights are well protected in such regions, which stimulate entrepreneurial experimentation, innovation and technology transfer by foreign firms. Weak market development, by contrast, tends to be associated with weak channels for technology transfer to local firms (Tihanyi and Roth 2002). Research also shows that well-established market institutions in the host country help foreign firms develop competitive advantages (McEvily and Zaheer 1999) that enhance performance. Therefore, as well-established markets facilitate technology transfer by foreign firms, they create a greater potential for spillovers to occur. By contrast, poorly developed markets and institutions may pose challenges for foreign firms and reduce their willingness to transfer technology, thus reducing the scope for potential spillovers.

Second, the level of marketization in a region influences domestic firms' ability to learn from foreign firms, and thus facilitates or constrains the evolution of absorptive capacity in domestic firms (Meyer and Nguyen 2005). Well-established regional institutions facilitate the exchange of factors for value creation, which in turn helps firms acquire new and extend existing innovative and imitative capabilities (McEvily and Zaheer 1999). For example, regions with a well-functioning labor market that facilitates labor mobility and 
accumulation of human capital can help domestic firms develop absorptive capacity by recruiting managers and engineers from foreign firms. Similarly, the quality of educational institutions is higher in regions with well-developed market mechanisms because education is constantly upgraded and refined (Engelbrecht 1997). This allows firms to recruit high quality graduates. By contrast, in regions in which the market system is underdeveloped, institutional arrangements are often inconsistent and unclear. This increases transaction costs and makes it more difficult for firms to exploit potential externalities. Hence:

Hypothesis 2: The effects of foreign presence on the productivity of local firms will be higher in regions with a higher degree of marketization than in regions with a lower degree of marketization.

International openness (e.g., through trade or FDI) plays an important role in facilitating knowledge spillovers across borders because it encourages the spread of knowledge among trading partners (Grossman and Helpman 1991). However, although international openness policies are set at country level, their implementation often takes place at a regional level (Meyer and Nguyen 2005), leading to variations in international openness across subnational regions within a given country. For example, although the Chinese government has adopted a favorable attitude toward FDI, the implementation of these policies is often local. Some regions in China opened earlier than others to allow foreign investment. This makes international openness in China "spatially and structurally uneven" (He et al. 2008). As a result, the degree of international openness varies substantially across regions within China.

We argue that these variations in international openness across regions influence the relationship between foreign presence and domestic firms' productivity. First, international openness raises the level of competition in a subnational region, which is an important mechanism through which FDI spillovers occur because it forces these firms to become more efficient (Kokko et al. 1996). Domestic firms in these regions are likely to develop the strategic flexibility and learning practices that strengthen their ability to take advantage of foreign presence and enhance productivity (Keller 1996). Second, local firms in an open trade regime can acquire complementary technologies that help them perform reverse engineering, which is the basis of technology imitation and adoption. Because foreign investors in more open regions are likely to be highly integrated into the international trade system and adopt internationally competitive technologies, local firms in the same region can observe the latest technologies. This enables them to develop technological capabilities to allow them to reap FDI spillovers (Meyer and Siniani 2008). Third, an international openness encourages export-oriented foreign investors that may enhance the business opportunities for local firms in the same 
region, both directly by integrating into MNEs' supply networks, and indirectly by providing information on foreign markets and competitors (Kokko et al. 2001). It may even help local firms become exporters themselves (Aitken et al. 1997; Wang et al. 2007).

However, there is an opposing view that suggests that international openness may not increase the benefits of FDI spillovers. This view argues that because domestic firms in regions with a higher level of international openness already face foreign competition, they have less to learn from the presence of foreign firms (Blomström and Sjöholm 1999). Nevertheless, we overall expect FDI spillovers to be stronger in regions with a higher level of international openness than in regions with a lower level of international openness. Hence:

Hypothesis 3: The effects of foreign presence on the productivity of local firms will be stronger in regions with a higher degree of international openness than in regions with a lower degree of international openness.

\section{Data and Methodology}

Sample

Our dataset is composed of domestic firms and affiliates of MNEs operating in the Chinese manufacturing industry during the period 2005-2007, as retrieved from the Annual Census of Chinese Industrial Firms compiled by the National Bureau of Statistics of China (NBS). In China, all firms have to register with the NBS and report a number of different pieces of information, including their balance sheet data. The Census collects and provides detailed firm-level financial and operational information for all firms with an annual turnover of over five million Renminbi (around \$680,000). It is one of the most comprehensive datasets ever compiled by the NBS, accounting for about 90 per cent of total output in most industries. The NBS has attempted to maintain consistency in data collection across time, industries and regions (Zhou and Li 2008). We have undertaken extensive data checks for coding errors, missing values and organizational changes (e.g., entry and exit dynamics, mergers and acquisitions). This process removed 30,644 firms out of the total of 388,602 firms, leaving us a final dataset of 357,958 firms, covering 30 two-digit manufacturing sectors throughout 31 provinces, autonomous regions and municipalities in China.

To test our hypotheses, we sought information for every firm on its location within each of the 31 Chinese regions and obtained region-specific institutional data from various issues of the Statistical Yearbook of China published by the NBS. We compiled data on regional marketization from Fan et al. (2010). We deflated the 
balance sheet data using industry-specific price indices obtained from the Statistical Yearbook of China. Finally, we followed the regulations of the Chinese government and coded a firm as foreign if more than 25 percent of its capital belonged to an MNE. Table 1 presents information on foreign entry and exit in our sample during 2005-2007. The number of MNEs increased significantly over the sample period, but the rate of MNE penetration remains stable (about 10 per cent of total firms in the sample). The data suggest that while the rate of exit is higher than that of entry, the presence of foreign MNEs remains high and stable over the sample period.

(Insert Table 1 about here)

Measures

Dependent variable

The dependent variable is the total factor productivity $(T F P)$ of domestic firms. We estimated productivity measures through a semi-parametric procedure proposed by Levinsohn and Petrin (2003). The ordinary least squares estimator treats labor and other inputs as exogenous variables and is not able to handle endogenous inputs (Griliches and Mairesse, 1995). Olley and Pakes (1996) developed a similar semi-parametric estimator, but solved the problem of endogeneity by using the investment decision to proxy unobserved productivity. However, the monotonicity condition requires that investment always leads to increase in productivity and thus only observations with positive investment can be used. Some firms under consideration in this paper report zero investment in a significant number of cases, implying a significant loss of efficiency in estimation. We therefore followed the procedure of Levinsohn and Petrin (2003) to estimate TFP. This procedure allows us to use intermediate inputs rather than investment as a proxy for unobserved productivity effects, and retain most observations in the estimation.

\section{Independent variables}

The key independent variable is $F D I$, which measures the level of presence of MNEs. In international business, the presence of MNEs is often operationalized by the ratio of multinational employees over total employment in a given industry-region in a given year. However, Altomonte and Pennings (2009) argue that an equal proportional increase in the MNEs' employment and the total employment will have no effect on domestic firms' productivity, and therefore downwardly bias the estimate of spillovers. Wang et al. (2012a) show that the number of MNEs and the capital stock of MNEs in the same industry-region pair are highly correlated with each another. Following these studies, we use the number of MNEs operating in a given industry-region in a given year to identify the presence of MNEs. 
We include three region-specific institutional variables that may moderate the effects of FDI on domestic firms' productivity. IPR efficiency is measured as the ratio of settled IP lawsuits to the total number of IP lawsuits in a region. The data are obtained from the website of the State Intellectual Property Office of China (SIPO). Administrative decentralization has led provincial governments to have substantial judicial independence and frequently to influence courts' judgments (Peck and Zhang, 2013). Thus, even though a unified IPR law applies throughout China, IPR enforcement and efficiency differs significantly across regions in the country due to uneven regional development in institutions and markets. A higher ratio of the region-specific IPR enforcement indicates a stronger regime of IPR protection in the region.

Furthermore, we follow Yi et al. (2013) and Hong et al. (2014) to operationalize marketization using a measure developed by Fan et al. (2010) for 2005-2007. This is a comprehensive composite index that evaluates the development of market-based mechanisms in each of China's regions. It covers five key areas, comprising the role of market relative to government, the development of the private sector, the development of commodity markets, the development of factor markets, and the development of free market institutions using a total of twenty-six indicators. The index is similar to the Heritage Foundation Index of Economic Freedom which provides a measure of nine characteristics that reflect a country's adherence to free-market principles (Meyer et al. 2009). A higher score indicates a higher level of market development. In addition, international openness is an institutional arrangement with a bunch of significant policy incentives facilitating MNEs' entry and operation in the host country. Following numerous studies (e.g., Goldberg and Grosse 1994; Ortega and Peri, 2014), international openness is measured by the ratio of imports and exports to GDP in the province-level region. A higher ratio implies a greater degree of international openness.

\section{Control variables}

The model includes several variables to control for firm-level unobserved heterogeneity. We first include firm size, which is measured by the natural logarithm of total number of employees. Since a firm's age can increase productivity by facilitating the accumulation of knowledge and experience, we control for such effects by including firm age, measured by the number of years since the firm was founded. Because ownership influences a firm's incentive and ability to benefit from FDI (Buckley et al. 2007b), we control for this effect by including state ownership which is measured by a dummy (=1 if state owned). As firm competencies may also affect its productivity, we follow Gao et al. (2010) to control this effect using cost leadership competencies and differentiation competencies. Cost leadership is measured using the ratio of a firm's production costs to total sales over the industry's average production costs to total sales, while differentiation 
competency is measured by ratio of a firm's R\&D expenditures to total sales over the industry's average R\&D expenditures to total sales. In addition, region-specific technological capability affects the absorptive ability of domestic firms and thus neighbouring MNEs' spillovers. We operationalize this variable as the ratio of R\&D expenditure to GDP in the province-level region. The $R \& D$ expenditure is the spending on $R \& D$ from governments, agencies, universities and enterprises in a region.

Finally, dummy variables are introduced to account for idiosyncrasies associated with industry, region and time variations. Two-digit industry dummies are included to control for industrial differences that may affect variations in firm productivity. Given that China features significant regional differences in economic and institutional development, the models also include regional dummy variables to control for other characteristics of the region in which the firm is located in addition to region-specific institutions. Year dummies are annual time effects, thus controlling for the effects of temporal variations such as fluctuations in exchange rate and other time-varying factors on firm productivity. Table 2 summarizes the variables and their expected effects on firm productivity.

(Insert Table 2 about here)

\section{Results}

Table 3 reports the descriptive statistics. The correlations among the independent variables are fairly low except those between FDI and marketization and between FDI and international openness which are well expected. The variance inflation factor (VIF) ranges from 1.03 to 2.87 , and the average value is well below the acceptable level of 10 (Neter et al. 1985), indicating that multicollinearity is not a concern. Nevertheless, following the usual practice (Aiken and West 1991), we mean-centered the interaction terms to avoid any possible problems of multicollinearity. The key independent variables are lagged by one year to account for the fact that spillover effects take some time to materialize. Furthermore, a lag structure allows us to control for a possible simultaneity bias (Aitken and Harrison 1999). Although our model incorporates several variables that account for firm characteristics which help to control for the estimation bias associated with unobserved firm-level heterogeneity, we use panel data methods to control for such effects. To do this, it was necessary to make a choice between fixed and random effects models. The choice between the two depends on whether the unobserved individual effects correlate with the observed explanatory variables in the model. The random effects model is preferred to the fixed effects model if the correlation between the unobserved effects and the regressors is low. Otherwise, the fixed-effects model is more appropriate. As the Hausman test in Table 4 reveals a correlation between the firm-specific error component and the explanatory variables, this indicates 
that we can reject the null hypothesis of the random effects model for all models. We therefore use the fixed effects estimations. The adoption of the fixed effects estimation is also consistent with most studies on FDI spillovers (Liu et al. 2009; Wang et al. 2012a), because this approach can well control for unobserved heterogeneity such as high-quality management, infrastructure and technology opportunity, which may affect the correlation between foreign presence and productivity enhancement in firms. Table 4 shows the results.

(Insert Table 4 about here)

Model 1 serves as the baseline model as it includes the key independent variable (FDI) and control variables only. The coefficient of the FDI variable is positive and statistically significant. This result remains unchanged after the variables for region-specific institutions are added in Model 2. This suggests that the presence of foreign firms may indeed positively impact the productivity of domestic firms. This finding is consistent with the literature on China (e.g., Liu and Wei 2006, 2009; Buckley et al. 2002, 2007a) and on other countries such as Mexico (Jordaan 2008), Uruguay (Kokko et al. 1996) and Indonesia (Sjöholm 1999). Model 2 shows that all the three institutional variables (IPR efficiency, marketization and international openness) negatively impact productivity. This is not surprising, because all three institutional variables can influence firm productivity either positively or negatively. For example, IPR protection can create a knowledge filter and reduce the diffusion of knowledge in the economy (Acs et al. 2004). Arguably, the effects of these region-specific institutions will depend on a wide range of other region- and firm-specific idiosyncrasies.

As our main focus is the moderating effect of region-specific characteristics on the relationship between foreign presence and domestic firms' productivity, we are particularly interested in the coefficients of the interaction terms. In line with our expectation, the interaction term in Model 3 is positive and statistically significant, supporting $\mathrm{H} 1$ that suggests that the effects of foreign presence on the productivity of local firms will be higher in regions with stronger IPR protection than in regions with weaker IPR protection. Similarly, the significant coefficient of the interaction term in Model 4 provides support for $\mathrm{H} 2$, suggesting that market development enhances FDI spillovers. As for the moderating effects of international openness, the interaction term in Model 5 is also positive and statistically significant. This result corroborates H3, suggesting that international openness in a region may act as a catalyst for the relationship between foreign presence and domestic firms’ productivity.

\section{Discussion and Conclusion}


Building on institutional theory (e.g., North, 1990), this paper develops a conceptual framework that demonstrates how the regional institutional context may constitute a core component in understanding FDI spillovers. Our contribution lies in identifying and documenting the mechanisms through which region-specific institutions influence the effects of FDI on the productivity of domestic firms in emerging markets. Using a comprehensive panel dataset of Chinese manufacturing firms, we find that domestic firms in regions with higher levels of IPR enforcement, market development and international openness are better able to benefit from the presence of foreign firms in the same region. The findings support our framework and hypotheses, and have several implications for research on FDI spillovers.

First, prior research suggests that regional institutions within a given country influence the location choices of foreign firms (Meyer and Nguyen 2005; Zhou et al. 2002) and their performance (Khanna and Rivkin 2001; North 1990). We extend this literature by explaining how region-specific institutions also influence the spillover effects of FDI. We argue that region-specific institutional idiosyncrasies affect the existence and magnitude of FDI spillovers by influencing foreign firms' willingness to transfer, develop and protect technology, local firms' absorptive capacity and the ways in which the two types of firms interact. By bringing institutional contexts to the foreground and conceptualizing institutions as a part of the process of spillover generation, our analysis extends the literature on FDI spillovers that has previously relied on the resource-based view and absorptive capacity to explain how and when local firms benefit from the presence of foreign firms. The findings imply that future studies should explicitly incorporate the role of the institutional peculiarities of different locations within a country to account more fully for the factors that determine FDI spillovers.

Second, it is often assumed that IPR protection may reduce spillovers by increasing value appropriation and facilitating the commercialization and licensing of technologies (Gans et al. 2008). Our findings challenge this traditional view by revealing that the benefits of FDI spillovers are actually stronger for domestic firms that operate in regions with stronger IPR enforcement than for their counterparts in other regions. Although it is difficult to establish whether these effects pertain to the setting of emerging markets only, the results suggest that IPR protection can indeed either enhance or constrain FDI spillovers. This view is in line with recent evidence showing that IPR protection has a non-linear effect on innovation (e.g., Gould and Gruben 1996) as non-linearity implies co-existence of both positive and negative effects.

Finally, many emerging economies have implemented pro-market reforms to strengthen market oversight mechanisms (Frye and Shleifer 1997; Khanna and Palepu 1997). Previous studies show that such reforms 
improve firm competitiveness and performance (Dau 2013; Cuervo-Cazurra and Dau 2009). However, although pro-market reforms can be beneficial for both foreign and local firms, it is not clear how such reforms affect domestic firms in terms of increased inflow of FDI and thus the heightened level of competition between foreign and local players. Prior research has largely ignored how market development in emerging economies, as a result of pro-market reform, shapes FDI spillovers. We show that region-specific marketization enhances beneficial spillovers which increases the productivity of domestic firms. We contribute to the literature on pro-market reforms and firm performance by showing how pro-market reforms improve the performance of domestic firms by enhancing the benefits of FDI. Our analysis also enriches this stream of literature by showing how openness facilitates FDI spillovers. Additionally, prior research on FDI focuses largely on national level institutions. Our findings, regarding the region-specific institutional effects, challenge the implicit assumption of institutional homogeneity within a given country. Such an approach may reveal sub-relationships in the data that up to now have remained hidden within the aggregate relationships of institutions, FDI and performance of domestic firms reported in most studies.

This study also has important policy implications. The belief that FDI generates technological spillovers has led local governments in emerging markets to use incentive packages such as tax breaks, job creation subsidies and preferential loans to attract foreign investments. These FDI policies, however, are sometimes criticized as discriminatory to domestic firms (Yao and Zhang 2008). In this study, we show that another policy option that local governments could adopt would be to improve region-specific institutions by strengthening the enforcement of IPR laws, deepening market-oriented reforms and further enhancing international openness through trade and FDI in their jurisdiction. All of this can facilitate the generation of spillovers from inward FDI. Furthermore, prior research highlights the importance of strengthening the absorptive capacity of domestic firms for reaping FDI spillovers. Our analysis postulates the crucial role of well-developed institutions in enhancing such a capacity. The findings of this study translate into policy advice for regional FDI agencies in emerging and transition countries, which are often caught in autocratic regimes that do not necessarily envision institutional development as pivotal for domestic firms to harness FDI spillovers.

A number of limitations, however, should be kept in mind. First, our empirical data, as in many previous studies, rely on one country. Although China represents a fruitful contextual setting for the subject matter, and indeed our framework may apply to other emerging economies such as Vietnam which also features significant variations across subnational regions (Meyer and Nguyen 2005), the findings of the study may not be equally 
generalizable to other emerging countries because of various China-specific idiosyncratic characteristics in terms of the economic, social and institutional conditions. Second, we have considered the effects of three important region-specific institutions, but data constraints do not allow us to consider other region-specific institutional idiosyncrasies, such as region-specific FDI policies and other norms and regulations. These may also shape how foreign and local firms interact and thus affect the spillover effects of FDI. Third, in examining the role of several region-specific institutions, this study has assumed that all foreign investors react to these institutional forces in a similar fashion. A central premise in international business theory is that ownership advantages and the motivations for FDI vary with the nationality of the investor and its prior experience (Buckley et al. 2007). Thus, it would be valuable to examine how foreign investors from different countries are affected by region-specific institutions which may in turn lead to differential effects on domestic firms.

In summary, we have argued that institutions vary across regions within a given country and such differences can account for a significant portion of the variations in FDI spillovers. Our findings support this premise, showing that firms that operate in regions with higher levels of intellectual property right (IPR) protection, market development and international openness are better able to absorb spillovers and improve their productivity. Therefore, the paper extends prior literature on the determinants of FDI spillovers which has largely focused either on firm- and industry-specific determinants or on country-level institutional idiosyncrasies by demonstrating how variations in region-specific institutions shape the effects of FDI on productivity of local firms. 


\section{References}

Acs, Z., Audretsch, D., Braunerhjelm, P., \& Carlsson, B. (2004). The missing link: The knowledge filter and entrepreneurship in endogenous growth. Center for Economic Policy Research Discussion Paper No. 4783.

Aiken, L., \& West, S. (1991). Multiple regression: Testing and interpreting interactions. Newbury Park, CA: Sage Publications.

Aitken, B., Hanson, G., \& Harrison, A, (1997). Spillovers, foreign investment, and export behaviour. Journal of International Economics, 43 (1-2), 103-132.

Aitken, B., \& Harrison, A. E. (1999). Do domestic firms benefit from direct foreign investment? Evidence from Venezuela. American Economic Review, 89(3), 605-618.

Ali, I., Rehman, K. U., Yilmaz, A. K., Nazir, S., Ali, J. F. (2010). Effects of corporate social responsibility on consumer retention in cellular industry of Pakistan. African Journal of Business Management, 4(4), $475-485$

Altomonte, C., \& Pennings, E. (2009). Domestic plant productivity and incremental spillovers from foreign direct investment. Journal of International Business Studies, 40(7), 1131-1148.

Antal-Mokos, Z. (1998). Privatisation, politics, and economic performance in Hungary. New York: Cambridge University Press.

Blomström, M., \& Sjöholm, F. (1999). Technology transfer and spillovers: Does local participation with multinationals matter? European Economic Review, 43(4-6), 915-923.

Boisot, M. H., \& Child, J. (1996). From fiefs to clans and network capitalism: Explaining China's emergent economic order. Administrative Science Quarterly, 41(4), 600-628.

Boisot, M. \& Meyer, M. (2008). Which way through the open door? Reflections on the internationalization of Chinese firms. Management and Organization Review, 4(3), 349-365.

Buckley, P. J., Clegg, J., \& Wang, C. (2002). The impact of inward FDI on the performance of Chinese manufacturing firms. Journal of International Business Studies, 33(4), 637-655.

Buckley, P. J., Clegg, J., \& Wang, C. (2007a). Is the relationship between inward FDI and spillover effects linear? An empirical examination of the case of China. Journal of International Business Studies, 38(3), 447-459. 
Buckley, P., Clegg, J., \& Wang, C. (2007b). The impact of foreign ownership, local ownership and industry characteristics on spillovers from foreign direct investment in China. International Business Review, $16(2), 142-158$.

Buckley, P. J., Elia, S., \& Kafouros, M. (2014). Acquisitions by emerging market multinationals: Implications for firm performance. Journal of World Business, forthcoming.

Chan, C.M., Makino, S., \& Isobe, T. (2010). Does subnational region matter? Foreign affiliate performance in the United States and China. Strategic Management Journal, 31(11), 1226-1243.

Chen, Y., \& Puttitanun, T. (2005). Intellectual property rights and innovation in developing countries. Journal of Development Economics, 78 (2), 474-493.

Cheung, K., \& Lin, P. (2004). Spillover effects of FDI on innovation in China: Evidence from the provincial data. China Economic Review, 15(1), 25-44.

State Statistical Bureau of China (SSB). (2008). China Statistical Yearbook. China Statistical Press.

Coriat, B., \& Weinstein, O. (2002). Organizations, firms and institutions in the generation of innovation. Research Policy, 31(2), 273-290.

Cuervo-Cazurra, A. and Dau, L.A. (2009). Pro-market reforms and firm profitability in developing countries. Academy of Management Journal, 52(6), 1348-1368.

Cui, L., \& Jiang, F. (2012). State ownership effect on firms' FDI ownership decisions under institutional pressure: A study of Chinese outward-investing firms. Journal of International Business Studies, 43(3), 264-284.

Dau, L. A. (2013). Learning across geographic space: Pro-market reforms, multinationalization strategy, and profitability. Journal of International Business Studies, 44(3), 235-262.

Du, J., Lu, Y. \& Tao, Z. (2008). Economic institutions and FDI location choice: Evidence from US multinationals in China. Journal of Comparative Economics, 36(3), 412-429.

Dunning, J. H. (1993). Multinational enterprises and the global economy. Wokingham: Addison-Wesley.

Engelbrecht, H.-J. (1997). International R\&D spillovers, human capital and productivity in OECD economies: an empirical investigation. European Economic Review, 41(8), 1479-1488.

Fan, G., Wang, X., \& Zhu, H. (2010). NERI index of marketization of China's provinces 2009 report. Beijing: Economic Science Press.

Feinberg, S., \& Majumdar, S. K. (2001). Technology spillovers and foreign direct investment in the Indian pharmaceutical industry. Journal of International Business Studies, 32(3), 421-437. 
Fortanier, F. (2007). Foreign direct investment and host country economic growth: Does the investor's country of origin play a role? Transnational Corporations, 16(2), 41-76.

Frye, T., \& Shleifer, A. (1997). The invisible hand and the grabbing hand. American Economic Review: Papers and Proceedings, 87(2), 354-358.

Gans, J. S., Hsu, D. H., \& Stern, S. (2008). The impact of uncertain intellectual property rights on the market for ideas: Evidence from patent grant delays. Management Science, 54(5), 982-997.

Gao, G. Y., Murray, J. Y., Kotabe, M., \& Lu, J. (2010). A 'Strategy Tripod’ perspective on export behaviors: Evidence from domestic and foreign firms based in an emerging economy. Journal of International Business Studies, 41(6), 377-396.

Girma, S. (2005). Absorptive capacity and productivity spillovers from FDI: a threshold regression analysis. Oxford Bulletin of Economics and Statistics, 67(3), 281-306.

Girma, S., Gorg, H., \& Pisu, M. (2007). Exporting, linkages and productivity spillovers from foreign direct investment. CEPR Discussion Paper No. 6383.

Girma, S., Greenaway, D., \& Wakelin, K. (2001). Who benefits from foreign direct investment in the UK? Scottish Journal of Political Economy, 48 (2), 119-133.

Goldberg, L. G., \& Grosse, R. (1994). Location choice of foreign banks in the United States. Journal of Economics and Business, 46 (5), 513-533.

Görg, H., \& Greenaway, D. (2004). Much ado about nothing? Do domestic firms really benefit from foreign direct investment? World Bank Research Observer, 19(2), 171-197.

Görg, H., \& Strobl, E. (2001). Multinational companies and productivity spillovers: a Meta-Analysis. The Economic Journal, 111(475), F723-F739.

Gould, D. M., \& Gruben, W. C. (1996). The Role of Intellectual Property Rights in Economic Growth. Journal of Development Economics, 48(2), 323-350.

Grabher, G., \& Stark, D. (1997). Restructuring networks in post-socialism. Oxford, UK: Oxford University Press.

Griliches, Z., \& Mairesse, J. (1995). Production functions: The search for identification. NBER Working Paper No. 5067, Washington, DC.

Grossman, G. \& Helpman, E. (1991). Quality ladders in the theory of growth. The Review of Economic Studies, 58(1), 43-61. 
Hale, G., \& Long, C. (2011). Did foreign direct investment put an upward pressure on wages in China? IMF Economic Review, 59(3), 404-430.

Haskel, E. J., Pereira, C. S., \& Slaughter, J. M. (2002). Does foreign direct investment boost the productivity of domestic firms? Working Paper No. 452, Department of Economics, Queen Mary, University of London.

He, C., Wei, D. W., \& Xie, X. (2008). Globalization, institutional change, and industrial location: economic transition and industrial concentration in China. Regional Studies, 42(1), 1-23.

Holmes, T.J., McGrattan, E.R., \& Prescott, E.C. (2014). Quid Pro Quo: Technology Capital Transfers for Market Access in China. Federal Reserve Bank of Minneapolis, Research Department Staff Report, 486.

Hong, J., Wang, C., \& Kafouros, M. (2014). The role of the state in explaining the internationalization of emerging market enterprises. British Journal of Management, forthcoming.

Huang, L., Liu, X., \& Xu, L. (2012). Regional innovation and spillover effects of foreign direct investment in China: A threshold approach. Regional Studies, 46(5), 583-596.

Jaffe, A. B., \& Lerner, J. (2004). Innovation and its discontents: How our broken patent system is endangering innovation and progress, and what to do about it. Princeton, NJ and Oxford: Princeton University Press.

Jordaan, J. A. (2008). Intra- and inter-industry externalities from foreign direct investment in the Mexican manufacturing sector: New evidence from Mexican regions. World Development, 36(12), 2838-2854.

Kafouros, M. I. (2008). Industrial innovation and firm performance: The impact of scientific knowledge on multinational corporations. Cheltenham: Edward Elgar Publishing.

Kafouros, M. I., Buckley, P. J. (2008). Under what conditions do firms benefit from the research efforts of other organizations? Research Policy, 37(2), 225-239.

Kafouros, M. I., Buckley, P. J., \& Clegg, J. (2012). The effects of global knowledge reservoirs on the productivity of multinational enterprises: The role of international depth and breadth. Research Policy, $41(5), 848-861$.

Ke, S., \& Lai, M. (2011). Productivity of Chinese regions and the location of multinational research and development. International Regional Science Review, 34 (1), 102-131.

Keller, W. (1996). Absorptive capacity: On the creation and acquisition of technology in development. Journal of Development Economics, 49(1), 199-227.

Khanna, T., \& Palepu, K. (1997). Why focused strategies may be wrong for emerging markets. Harvard Business Review, 75(July-August), 41-51. 
Khanna, T., \& Rivkin, J. W. (2001). Estimating the performance effects of business groups in emerging markets. Strategic Management Journal, 22(1), 45-74.

Khanna, T., \& Yafeh, Y. (2007). Business groups in emerging markets: Paragons or parasites. Journal of Economic Literature, 45(2), 331-372.

Kokko, A., Tasini, R. and Zejan, M. (1996). Local technological capability and productivity spillovers from FDI in the Uruguayan manufacturing sector. Journal of Development Studies, 32(4), 602-611.

Kokko, A., Tasini, R., \& Zejan, M. (2001). Trade regimes and spillover effects of FDI: Evidence from Uruguay. WeltwirtschaftlichesArchiv, 137(1), 124-149.

Lee, K., \& Kim, B. (2009). Both institutions and policies matter but differently for different income groups of countries: Determinants of long-run economic growth revisited. World Development, 37 (3), 533-549.

Levinsohn, J., \& Petrin, A. (2003). Estimating production functions using inputs to control for unobservables. Review of Economic Studies, 70(2), 317-342.

Liu, X., Wang, C., \& Wei, Y. (2009). Do local manufacturing firms benefit from transactional linkages with multinational enterprises in China? Journal of International Business Studies, 40 (7), 1113-1130.

Luo, Y., \& Tung, R. L. (2007). International expansion of emerging market enterprises: A springboard perspective. Journal of International Business Studies, 38(4): 481-498.

Makino, S., \& Beamish, P. W. (1998). Performance and survival of international joint ventures with non-conventional ownership structures. Journal of International Business Studies, 29(4), 797-818.

Maskus, K. E. (2000). Intellectual property rights in the global economy. Washington DC: Institute for International Economics.

McEvily, B., \& Zaheer, A. (1999). Bridging ties: A source of firm heterogeneity in competitive capabilities. Strategic Management Journal, 20(12), 1133-1156.

Meon, P.-G., \& Sekkat, K. (2005). Does corruption grease or sand the wheels of growth. Public Choice, 122(1-2), 69-97.

Meyer, K. E. (2001). Institutions, transaction costs and entry mode choice in Eastern Europe. Journal of International Business Studies, 31(2), 357-367.

Meyer, K. E., Estrin, S, Bhaumik, S. K., \& Peng, M. W. (2009). Institutions, resources, and entry strategies in emerging economies. Strategic Management Journal, 30(1), 61-80.

Meyer, K. E., \& Nguyen, H. V. (2005). Foreign investment strategies and subnational institutions in emerging markets: Evidence from Vietnam. Journal of Management Studies, 42(1), 63-93. 
Meyer, K., \& Sinani, E. (2008). When and where does foreign direct investment generate positive spillovers? A meta analysis. Journal of International Business Studies, 40(7), 1075-1094.

Mullen, J., \& Williams, M. (2007). Foreign direct Investment and regional productivity spillovers in US manufacturing. Review of Urban \& Regional Development Studies, 19(3), 185-196.

Nachum, L. (2000). Economic geography and the location of TNCs: Financial and professional service FDI to the US. Journal of International Business Studies, 31 (3), 367-385.

Neter, J., Wasserman, W., \& Kutner, M. H. (1985). Applied linear statistical models. Homewood, IL: Irwin.

North, D. C. (1990). Institutions, institutional change and economic performance. Cambridge: Cambridge University Press.

Olley, S., \& Pakes, A. (1996). The dynamics of productivity in the telecommunications equipment industry. Econometrica, 64(6), 1263-1298.

Ortega, F., \& Peri, G. (2014). Openness and income: The roles of trade and migration. Journal of International Economics, 92 (2), 231-251.

Peck, J., \& Zhang, J. (2013). A variety of capitalism . . . with Chinese characteristics? Journal of Economic Geography, doi:10.1093/jeg/lbs058.

Qi, J., Zheng, Y., Laurenceson, J. \& Li, H. (2009). Productivity spillovers from FDI in China: Regional differences and threshold effects. China \& World Economy, 17(4), 18-35.

Siebeck, W., Evenson, R., Lesser, W., \& Primo Braga, C. (1990). Strengthening protection of intellectual property in developing countries: A survey of the literature. World Bank discussion paper No. 112, Washington DC.

Sjöholm, F. (1999). Technology gap, competition and spillovers from foreign direct investment: Evidence from establishment data. Journal of Development Studies, 36(1), 53-73.

Tihanyi, L. \& Roth, A. S. (2002). Technology transfer and institutional development in Central and Eastern Europe. Journal of World Business, 37(3), 188-198.

Wang, C., Buckley, P., Clegg, J., \& Kafouros, M. (2007). The impact of foreign direct investment on Chinese export performance. Transnational Corporations, 16(2), 119-136.

Wang, C., Deng, Z., Kafouros, M., \& Chen, Y. (2012a). Reconceptualizing the spillover effects of foreign direct investment: A process dependent approach. International Business Review, 21 (3), 452-464. 
Wang, C., Hong, J., Kafouros, M., \& Wright, M. (2012b). Exploring the role of government Involvement in outward direct investment from emerging economies. Journal of International Business Studies, 43(7), 655-676.

Wei, Y., \& Liu, X. (2006). Productivity spillovers from R\&D, exports and FDI in China's manufacturing sector. Journal of International Business Studies, 37(4), 544-557.

Wright, M., Filatotchev, I., Hoskisson, R. E., \& Peng, M. W. (2005). Strategy research in emerging economies: Challenging the conventional wisdom - Introduction. Journal of Management Studies, 42(1), 1-33.

Yao, Y., \& Zhang, X. B. (2008). Race to the top and race to the bottom: Tax competition in rural [People's Republic of] China. IFPRI Discussion Paper No. 00799 09/2008.

Yi, J., Wang, C., \& Kafouros, M. (2013). The effects of innovative capabilities on exporting: Do institutional forces matter? International Business Review, 22 (2), 392-406.

Zhang, Y., Li, H., Li, Y., \& Zhou, L. (2010). FDI spillovers in an emerging market: The role of foreign firms' country origin diversity and domestic firms' absorptive capacity. Strategic Management Journal, 31(9), 969-989.

Zhou, C., Delios, A., \& Yang, J. Y. (2002). Locational determinants of Japanese foreign direct investment in China. Asia Pacific Journal of Management, 19(1), 63-86.

Zhou, C., \& Li, J. (2008). Product innovation in emerging market-based international joint ventures: An organizational ecology perspective. Journal of International Business Studies, 39(7), 1114-1132. 


\section{Figures and Tables}

\section{Figure 1 Moderating effects}

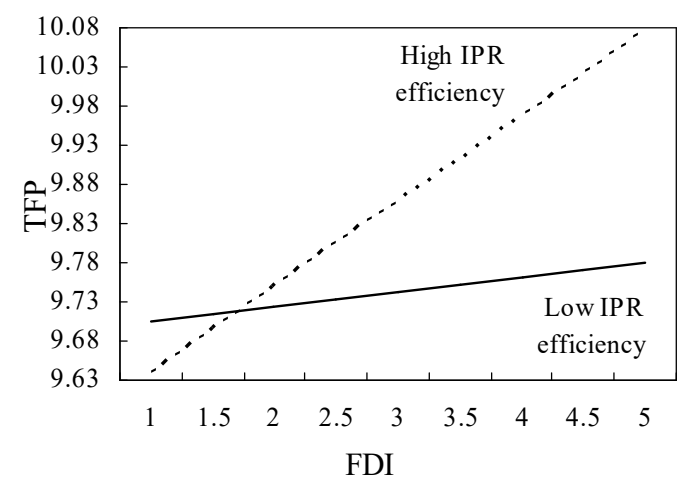

(a) The moderating role of IPR efficiency

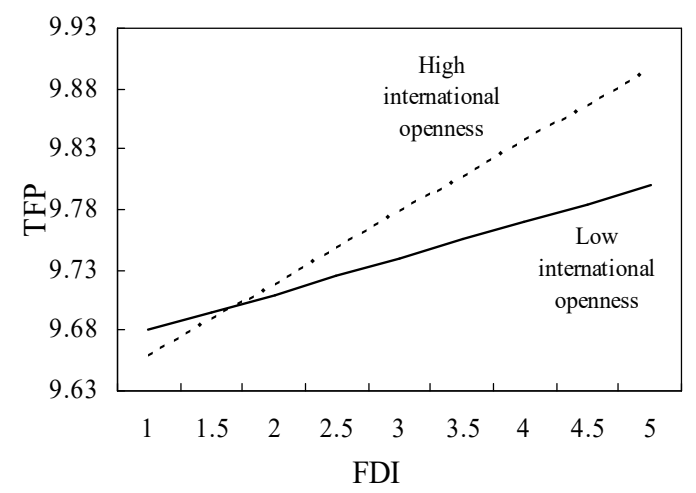

(c) The moderating role of international openness

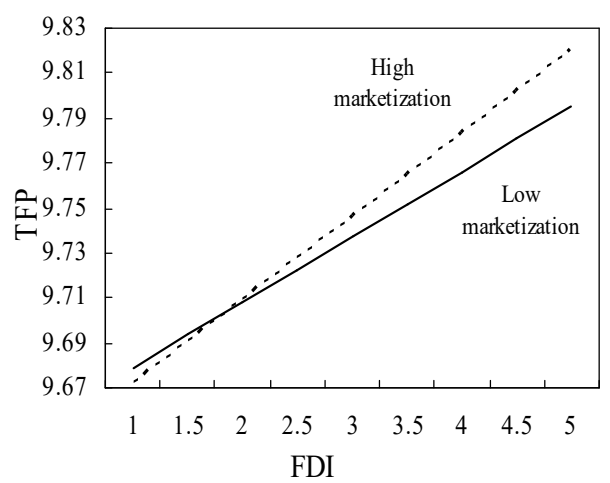

(b) The moderating role of marketization 
Table 1: Foreign entry and exit during 2005-2007

\begin{tabular}{ccccccc}
\hline Year & \multicolumn{3}{c}{ Number of firms } & MNE penetration & MNE entry rate & MNE exit rate \\
\cline { 2 - 4 } & Domestic & MNEs & Total & & & \\
\hline 2005 & 222,070 & 26,228 & 248,298 & 0.106 & & \\
2006 & 247,311 & 28,503 & 275,814 & 0.103 & 0.001 & 0.007 \\
2007 & 272,863 & 30,187 & 303,050 & 0.100 & 0.001 & 0.005 \\
\hline
\end{tabular}

Note: for MNEs, their foreign capital share in China is not less than $25 \%$. 
Dependent variable

TFP

Independent variable

FDI

\section{Moderators}

Region-specific IPR efficiency

Region-specific marketization

Region-specific international openness

\section{Control variables}

Firm size

Firm age

State ownership

Cost leadership competency

Differentiation competency

Region-specific technological capability

Industry dummy

Region dummy

Year dummy
Domestic firm-specific total factor productivity proposed by Levinsohn and Petrin (2003)

The number of foreign investments for not less than $25 \%$ capital share in a firm in the corresponding industry-region pair in a given year

Ratio of settling a lawsuit for patent infringement to filing the lawsuit in the corresponding province-level region +

Region-specific marketization index by Fan et al. (2010) in the corresponding province-level region

Ratio of imports plus exports to GDP in the corresponding province-level region

Log (number of employees)

Number of years since establishment

Dummy, equals to 1 if state-owned

Ratio of production costs/total sales in a firm to average production costs/total sales in a two-digit industry

Ratio of $R \& D$ expenditures/total sales in a firm to average $R \& D$ expenditures/total sales in a two-digit industry

Ratio of R\&D expenditure to GDP in the corresponding province-level region

Dummy, equals to 1 if affiliated at the corresponding two-digit industry

Dummy, equals to 1 if located at the corresponding province-level region

Dummy, equals to 1 if associated with the corresponding year 
Table 3: Descriptive statistics and correlation matrix of independent variables

\begin{tabular}{|c|c|c|c|c|c|c|c|c|c|c|c|c|c|}
\hline & \multirow{2}{*}{ Mean } & \multirow{2}{*}{$\begin{array}{l}\text { Standard } \\
\text { deviation }\end{array}$} & & & & & & & & & & & \\
\hline & & & 1 & 2 & 3 & 4 & 5 & 6 & 7 & 8 & 9 & 10 & 11 \\
\hline $1 \mathrm{TFP}$ & 9.736 & 1.184 & 1.00 & & & & & & & & & & \\
\hline 2 FDI & 4.244 & 1.581 & 0.01 & 1.00 & & & & & & & & & \\
\hline 3IPR efficiency & 0.896 & 0.078 & -0.03 & 0.06 & 1.00 & & & & & & & & \\
\hline 4 Marketization & 9.030 & 1.733 & -0.00 & 0.76 & 0.07 & 1.00 & & & & & & & \\
\hline 5 International openness & 0.722 & 0.554 & 0.00 & 0.58 & 0.01 & 0.76 & 1.00 & & & & & & \\
\hline 6Firm size & 4.638 & 1.080 & 0.59 & 0.00 & -0.05 & -0.04 & 0.02 & 1.00 & & & & & \\
\hline 7Firm age & 8.189 & 9.102 & 0.07 & -0.06 & 0.01 & -0.04 & 0.02 & 0.20 & 1.00 & & & & \\
\hline 8 State ownership & 0.033 & 0.179 & -0.06 & -0.13 & 0.00 & -0.13 & -0.05 & 0.06 & 0.37 & 1.00 & & & \\
\hline 9 Cost leadership competency & 1.000 & 7.351 & -0.03 & -0.00 & 0.00 & -0.00 & 0.00 & -0.00 & 0.00 & 0.01 & 1.00 & & \\
\hline 10 Differentiation competency & 1.000 & 14.959 & 0.01 & -0.01 & 0.01 & 0.00 & 0.01 & 0.03 & 0.02 & 0.02 & 0.31 & 1.00 & \\
\hline 11 Technological capability & 0.002 & 0.004 & -0.04 & -0.12 & 0.18 & -0.09 & 0.21 & -0.06 & 0.06 & 0.08 & 0.01 & 0.05 & 1.00 \\
\hline
\end{tabular}


Table4: Fixed effects regression of spillovers from FDI in China 2005-2007

\begin{tabular}{|c|c|c|c|c|c|}
\hline & Model 1 & Model 2 & Model 3 & Model 4 & Model 5 \\
\hline \multicolumn{6}{|l|}{ Independent variables } \\
\hline FDI & $0.012 * * *$ & $0.020 * * *$ & $0.019 * * *$ & $0.029 * * *$ & $0.030 * * *$ \\
\hline \multicolumn{6}{|l|}{ Moderators } \\
\hline IPR efficiency & & $-0.104 * * *$ & $-0.166 * * *$ & $-0.118 * * *$ & $-0.111 * * *$ \\
\hline Marketization & & $-0.126 * * *$ & $-0.131 * * *$ & $-0.124 * * *$ & $-0.127 * * *$ \\
\hline International openness & & $-0.348 * * *$ & $-0.303 * * *$ & $-0.353 * * *$ & $-0.344 * *$ \\
\hline \multicolumn{6}{|l|}{ Interactions } \\
\hline FDI *IPR efficiency (H1) & & & $0.090 * * *$ & & \\
\hline FDI *Marketization (H2) & & & & $0.008 * * *$ & \\
\hline FDI * International openness & & & & & $0.029 * * *$ \\
\hline \multicolumn{6}{|l|}{ Control variables } \\
\hline Firm size & $0.049 * * *$ & $0.050 * * *$ & $0.050 * * *$ & $0.050 * * *$ & $0.050 * * *$ \\
\hline Firm age & $0.001 * * *$ & $0.001 * * *$ & $0.001 * * *$ & $0.001 * * *$ & $0.001 * * *$ \\
\hline State ownership & 0.003 & 0.011 & 0.012 & 0.010 & 0.011 \\
\hline Cost leadership competency & $0.002 * * *$ & $0.002 * * *$ & $0.002 * * *$ & $0.002 * * *$ & $0.002 * * *$ \\
\hline Differentiation competency & $0.001 * * *$ & $0.001 * * *$ & $0.001 * * *$ & $0.001 * * *$ & $0.001 * * *$ \\
\hline Region-specific technological & $0.061 * * *$ & $0.021 * *$ & $0.029 * * *$ & $0.021 * *$ & $0.020 * *$ \\
\hline Industry dummies & Yes & Yes & Yes & Yes & Yes \\
\hline Region dummies & Yes & Yes & Yes & Yes & Yes \\
\hline Year dummies & Yes & Yes & Yes & Yes & Yes \\
\hline Sample size & 357550 & 357550 & 357550 & 357550 & 357550 \\
\hline Hausman test & $34077.41 * * *$ & $34198.00 * * *$ & $34287.83 * * *$ & $34211.76 * * *$ & $34227.49 * * *$ \\
\hline F-statistic & $608.89 * * *$ & $608.29 * * *$ & $600.81 * * *$ & $599.32 * * *$ & $599.36 * * *$ \\
\hline Adjusted $\mathrm{R}^{2}$ & 0.01 & 0.02 & 0.03 & 0.03 & 0.03 \\
\hline
\end{tabular}

Note: $* * *$ and $* * *$ are significantly different from zero at the $10 \%, 5 \%$ and $1 \%$ level respectively. 